Walicka M., Konsekwencje przystapienia Polski do strefy euro w percepcji przedsiębiorców, „Ekonomia i Prawo", Polszakiewicz B., Boehlke J. (red.), Tom XII, nr 4/2013, ss. 589-600. DOI: http://dx.doi.org/10.12775/EiP.2013.043

\title{
KONSEKWENCJE PRZYSTĄPIENIA POLSKI DO STREFY EURO W PERCEPCJI PRZEDSIĘBIORCÓW**
}

\section{STRESZCZENIE}

Obecna sytuacja gospodarcza oraz długoletnie doświadczenia krajów strefy euro skłaniają do coraz to nowych refleksji i wniosków. Pojawia się też potrzeba poszukiwania odpowiedzi na pytania: jakie konsekwencje przyniesie akcesja Polski do strefy euro dla małych i średnich przedsiębiorstw (MSP) oraz jakie nastawienie mają współcześni przedsiębiorcy do akcesji?

Celem artykułu jest przedstawienie stanowiska właścicieli MSP na temat przyjęcia wspólnej waluty. W artykule zastosowano wyniki badań ankietowych oraz wnioskowanie oparte na schemacie analitycznym, prowadzące do sporządzenia statystycznego rankingu potencjalnych bezpośrednich skutków członkostwa w strefie euro dla badanych. W rezultacie otrzymano katalog potencjalnych konsekwencji, stanowiących przyczynek do dalszych badań mikroekonomicznej perspektywy oddziaływania skutków ujednolicenia waluty na pozycję konkurencyjną MSP.

Słowa kluczowe: skutki przystąpienia do strefy euro, oczekiwania przedsiębiorców, MSP Klasyfikacja JEL: F15, F61, L20

* Monika Walicka, Politechnika Białostocka, Wydział Zarządzania, Katedra Finansów i Rachunkowości, ul. Ojca Tarasiuka 2, 16-001 Kleosin, tel. +48 8574698 48, e-mail: m.walicka@ pb.edu.pl.

** Artykuł powstał w ramach projektu „Rola handlu zagranicznego w procesie konwergencji. Przedsiębiorstwa handlowe szanse i zagrożenia w strefie euro" finansowanego przez Narodowy Bank Polski. 


\title{
CONSEQUENCES OF ACCESS TO EURO ZONE FROM ENTREPRENEURS' ATTITUDE
}

\author{
SUMMARY
}

Body of literature usually considers the consequences of joining the euro zone at the macroeconomic level. There are only a few publications describing not only the doubts of entrepreneurs, but also their attitudes and expectations about the adoption of a common currency system. The current economic situation along with long - time experience of euro zone states stimulate new reflections and conclusions. Apart from that, the need to answer some questions emerges: what will be the consequences for small and medium enterprises (SMEs) of Poland's participation in the euro zone and what is the current approach of entrepreneurs to the accession.

This article presents the attitude of the SME's owners to the opportunities and threats posed by the adoption of the euro currency. The method based on the analytical scheme was applied, leading to the compilation of statistical ranking of the potential benefits and risks of euro area membership. The result is a catalogue of potential consequences in a microeconomic perspective of the impact of currency standardization effects on the competitive position of SMEs.

Keywords: effects of euro zone access, opportunities and threats, SME

JEL Classification: F15, F61, L20

\section{WSTĘP}

Problem oceny konsekwencji przystąpienia do strefy euro jest trudny, ale wciąż aktualny dla Polski. W literaturze przedmiotu konsekwencje przystąpienia do strefy euro rozpatrywane są zwykle na poziomie makroekonomicznym. Niewiele jest publikacji opisujących wątpliwości przedsiębiorców, ich nastawienie i oczekiwania co do przyjęcia wspólnej waluty. Wagę zagadnienia podnoszą problemy pojawiające się w gospodarce światowej, a szczególnie w krajach unijnych. Sytuacja rynków finansowych w 2008 r. ukazała, że usztywnienie kursu może mieć negatywny wpływ na konkurencyjność gospodarek, przykładami są Litwa, Łotwa i Estonia. Okazuje się także, że partycypacja kraju w strefie euro nie gwarantuje mu likwidacji problemów związanych ze sferą finansów publicznych, jak to było w przypadku Grecji i Irlandii oraz innych krajów grupy PIIGS (Portugalii, Włoch, Hiszpanii) ${ }^{1}$. Struktural-

\footnotetext{
${ }^{1}$ Zob. szerzej: J.C. Shambaugh, R. Reis, H. Rey, The Euro's Three Crises, „Brookings Papers on Economic Activity”, Spring 2012, s. 157-231.
} 
na słabość strefy euro, obnażona przez trudności ekonomiczne tych krajów, nie wynika bezpośrednio ze słabości tej waluty ${ }^{2}$, lecz z braku respektowania reguł i zasad będących fundamentem funkcjonowania strefy ${ }^{3}$. Polska, posiadając płynny kurs walutowy, w 2009 r. była w stanie stłumić skutki kryzysu gospodarczego, a nawet podnieść swoją konkurencyjność na arenie międzynarodowej. W kontekście pewnych niedoskonałości strefy euro warto znów podjąć próbę odnalezienia odpowiedzi na pytania: czy przedsiębiorcy są zwolennikami przystąpienia do unii walutowej, czy akcesja uprości i przyspieszy ich rozliczenia w obrocie gospodarczym, czy zredukuje koszty działania i poprawi ich konkurencyjność na rynku międzynarodowym.

Celem artykułu jest przedstawienie opinii właścicieli małych i średnich przedsiębiorstw na temat bezpośrednich konsekwencji przystąpienia Polski do strefy euro dla ich przedsiębiorstw. W związku z tym, że badanie przeprowadzono na nielicznej próbie przedsiębiorstw ${ }^{4}$, przedstawione wyniki badań należy interpretować właśnie w tym kontekście. Wnioski i rezultaty pełnią funkcję postulatów do podejmowania dalszych, pogłębionych badań. W artykule przedstawiono jedynie wybrane ustalenia i wyniki badań, szczegółowa metodologia badań zaprezentowana została w publikacji J. Kilona ${ }^{5}$. W poszukiwaniu odpowiedzi na postawione pytania zastosowano metodę, popularną w naukach ekonomicznych i społecznych, w postaci schematu analityczne$\mathrm{go}^{6}$. Artykuł skonstruowano w postaci trzech części. Pierwsza $z$ nich stanowi przegląd literatury z zakresu potencjalnych i realnych konsekwencji przystąpienia Polski do strefy euro. Następnie zbadano nastawienie właścicieli małych i średnich przedsiębiorstw (MSP) do wejścia do UE oraz strefy euro pod kątem wpływu na konkurencyjność oraz oczekiwane przez nich konsekwencje, formułując ich ranking od najbardziej do najmniej istotnych.

2 M. Gorynia, M. Dzikowska, B. Jankowska, M. Pietrzykowski, P. Tarka, Przystapienie Polski do strefy euro a międzynarodowa konkurencyjnośc i internacjonalizacja polskich przedsiębiorstw, „Ekonomista”, nr 4/2011, s. 471.

${ }^{3}$ Konsekwentne rozluźnianie tych zasad przyczyniło się do trudności finansowych najbardziej zadłużonych krajów strefy.

${ }^{4}$ Badanie ankietowe metodą CAWI z zastosowaniem kwestionariusza ankiety przeprowadzono w 2013 r. na celowej próbie 36 przedsiębiorstw handlowych, w województwie podlaskim.

${ }^{5}$ Zob. szerzej: J. Kilon, Handel zagraniczny w procesie konwergencji - metodyka badań przedsiębiorstw handlowych wojewwództwa podlaskiego, „Ekonomia i Prawo”, B. Polszakiewicz, J. Boehlke (red.), t. 12, nr 4/2013.

${ }^{6}$ M. Gorynia et al., op. cit., s. 473; M. Gorynia, Luka konkurencyjna na poziomie przedsiębiorstwa a przystapienie Polski do Unii Europejskiej. Implikacje dla strategii firm i polityki gospodarczej, Wydawnictwo AE w Poznaniu, Poznań 2002, s. 11-12. 


\section{KONSEKWENCJE PRZYSTĄPIENIA DO STREFY EURO - DOTYCHCZASOWY STAN WIEDZY}

Temat skutków przystąpienia do strefy euro podejmowany jest od dawna ${ }^{7}$. Jednakże coraz częściej we współczesnej literaturze światowej pojawiają się wątpliwości, czy korzyści, które ma dać członkostwo w strefie euro, nadal są tak świetlane, jak wynika to z wcześniejszych założeń teoretycznych ${ }^{8}$. Podnoszona jest także dyskusja co do wpływu akcesji na konkurencyjność przedsiębiorstw ${ }^{9}$, w szczególności tych małych i średnich ${ }^{10}$.

Dostępne publikacje zawierają katalog potencjalnych konsekwencji przyjęcia jednolitej waluty. Wciąż jednak trwa dysputa na temat ich skali i stopnia zróżnicowania. Jednym $\mathrm{z}$ najczęściej przytaczanych argumentów za przystąpieniem do strefy euro jest redukcja ryzyka kursowego ${ }^{11}$ oraz kosztów transakcyjnych $^{12}$. W przypadku przedsiębiorstw oznacza to przede wszystkim redukcję kosztu pozyskania kapitału ${ }^{13}$. Badania przeprowadzone na poziomie różnych krajów także potwierdzają pozytywny wpływ przyjęcia wspólnej waluty na ryzyko kursowe ${ }^{14}$ oraz spadek ekspozycji na ryzyko kursowe (Francja, Słowacja) ${ }^{15}$.

7 J. Frieden, The Euro: Who Wins? Who Loses?, „Foreign Policy”, No. 112/1998, s. 24-40.

8 B.J. Cohen, The future of the euro: Let's get real, "Review of International Political Economy”, Vol. 19, No. 4/2012, „RIPE Focus on Governing Global Finance and Banking”, s. 689-700; P. R. Lane, The Real Effects of European Monetary Union, "The Journal of Economic Perspectives”, Vol. 20, No. 4/2006, s. 47-66.

9 C.R. Henning, Europe's Expanding Currency: Fiscal Stability and Democratic Legitimacy, „Review of International Political Economy", Vol. 14, No. 5/2007, s. 774-799.

${ }^{10}$ L.E. Brouthers, G. Nakos et al., Key Factors for Successful Export Performance for Small Firms, ,Journal of International Marketing”, Vol. 17, No. 3/2009, s. 21-38.

${ }_{11}$ M. Crozet, G. Lalanne, S. Poncet, Wholesalers in international trade, „European Economic Review", Vol. 58/2013.

${ }_{12}$ R. Portes, H. Rey et al., The Emergence of the Euro as an International Currency, „Economic Policy", Vol. 13, No. 26/1998, s. 305-343.

13 A. Bris, Y. Koskinen, M. Nilsson, The real effects of the euro: evidence from corporate investments, CEPR, „Discussion Paper”, No. 4521.

${ }^{14}$ J. Capstaff, A. Marshall, J. Hutton, The Introduction of the Euro and Derivative Use in French Firms, „Journal of International Financial Management”, Vol. 18/2007, s. 1-17.

${ }_{15} \mathrm{H}$. Nguyen, R. Faff, A. Marshall, Exchange rate exposure, foreign currency derivatives, and the introduction of euro: French evidence, „International Review of Economics and finance”, Vol. 16, No. 4/2007, s. 563-577; Y.W. Hung and H. Nguyen, Exchange rate exposure and the use of foreign currency derivatives in the Australian resources sector, "Journal of Multinational Financial Management”, Vol. 22, No. 4/2012, s. 151-167. 


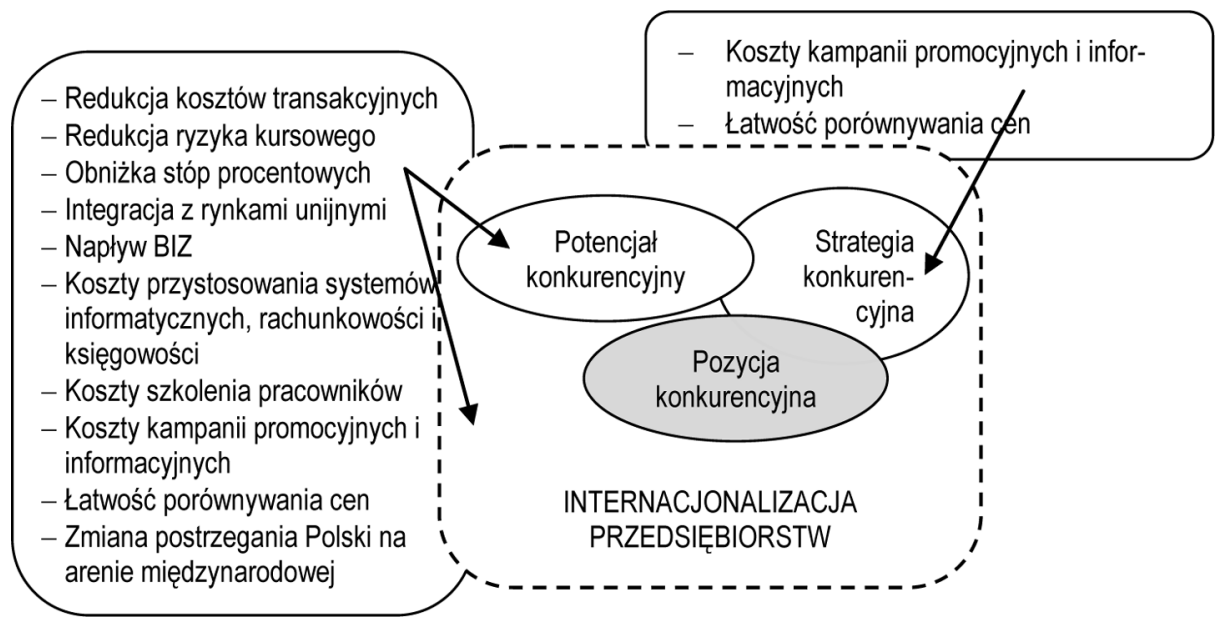

Rysunek 1. Schemat analityczny - strefa euro a konkurencyjność MSP

Źródło: opracowanie własne na podstawie: M. Gorynia i in., Przystapienie Polski do strefy euro a międzynarodowa konkurencyjność i internacjonalizacja polskich przedsiębiorstw, „Ekonomista”, nr 4/2011, s. 471-491; M. Gorynia i in., Opportunities and Threats Related to Accession of Poland to the Euro Zone - Perspective of Polish Enterprises, The Mechanism of Functioning of EMU Euro Zone Enlargement - The New Members Perspective, Wydawnictwo Uniwersytetu Łódzkiego, Łódź 2010, s. 55-65; M. Gorynia i in., Wpływ przyjęcia euro na międzynarodową konkurencyjność przedsiębiorstw, "Gospodarka Narodowa”, nr 4/ 2009, s. 1-23.

Liczne opracowania potwierdzają też wpływ integracji wewnątrz strefy euro na intensyfikację wymiany międzynarodowej ${ }^{16}$, jednakże skala tego wzrostu pozostaje trudna do zmierzenia. Szacunki w 2000 r. zakładały potrojenie wolumenu handlu pomiędzy krajami członkowskimi ${ }^{17}$, w 2002 r. Bun i Klas$\operatorname{sen}^{18}$ szacowali wzrost handlu na poziomie 38\%, w 2003 r. Micco, Stein i Ordone ${ }^{19}$ spodziewali się efektów na poziomie $10 \%$, Baldwin ${ }^{20}$ zaś oszacował je nieco mniej optymistycznie, na poziomie $5-10 \%$.

Do efektów bezpośrednio związanych z kondycją i otoczeniem ekonomicznym sektora przedsiębiorstw zaliczyć można zwłaszcza ${ }^{21}$ : spadek kosztów

16 N. Crespo, M.P. Fontoura, Intra-Industry Trade by Types: What Can We Learn from Portuguese Data?, „Review of World Economics”, Vol. 140, No. 1/2004, s. 52-79.

17 A.K. Rose, One Money, One Market: Estimating the Effect of Common Currencies on Trade, „Economic Policy”, No. 15/2000, s. 7-46.

18 M.J.G. Bun, F.J.G.M. Klaassen, The Euro Effect on Trade is not as Large as Commonly Thought, „Oxford Bulletin of Economics and Statistics”, No. 69/2007, s. 473-496.

19 A. Micco, E. Stein, G. Ordoñez, The Currency Union Effect on Trade: Early Evidence from EMU, „Economic Policy”, Vol. 18, No. 37/2003, s. 315-356.

${ }^{20}$ R. Baldwin, D. Taglioni, Trade Effects of the Euro: a Comparison of Estimators, "Journal of Economic Integration", Vol. 22, No. 4/2007, s. 780-818.

${ }^{21}$ K. Puchalska, Koszty dostosowawcze oraz korzyści z wprowadzenia euro dla sektora polskich przedsiębiorstw niefinansowych. Czego oczekuja polskie przedsiębiorstwa po przystapieniu do stre- 
transakcyjnych wymiany waluty krajowej na euro i spadek ryzyka kursowego $\mathrm{w}$ odniesieniu do transakcji rozliczanych w euro, wzrost wymiany handlowej w obrębie strefy euro, tzw. intra-Eurozone trade, poprawę dostępności kapitatu i spadek jego kosztu wskutek integracji rynku finansowego, stabilizację cen, spowodowaną ich większą transparentnością i wzrostem konkurencji rynkowej.

$\mathrm{Z}$ punktu widzenia percepcji przedsiębiorców można założyć, że skutki akcesji są kluczowe dla konkurencyjności przedsiębiorstw (rysunek 1.). Jedne $z$ nich wpływają na potencjał konkurencyjny, inne na stosowaną strategię, ale głównie - terminują pozycję konkurencyjną firmy w globalnej gospodarce.

\section{NASTAWIENIE WŁAŚCICIELI MAŁYCH I ŚREDNICH PRZEDSIĘBIORSTW DO PRZYSTĄPIENIA DO STREFY EURO - WYNIKI BADAŃ EKSPLORACYJNYCH}

Wielu badaczy wskazuje, że w procesach internacjonalizacji, w przypadku mniejszych przedsiębiorstw kluczowe może być nastawienie przedsiębiorcy - właściciela firmy ${ }^{22}$. Postanowiono rozpoznać nastawienie właścicieli małych i średnich przedsiębiorców do procesów globalizacji. Zadano im trzy pytania mające na celu poznanie ich opinii. Pierwsze pytanie (A) dotyczyło słuszności decyzji o przystąpieniu Polski do UE z punktu widzenia korzyści dla ich przedsiębiorstw. $Z$ tabeli 1 . wynika, że ponad połowa badanych dostrzega korzyści i ocenia przystąpienie do UE zdecydowanie pozytywnie. Tylko zaledwie nieco powyżej $11 \%$ wszystkich przedsiębiorców nie jest zadowolonych z tego procesu. $\mathrm{Na}$ zdecydowaną słuszność tej decyzji wskazują przede wszystkim mikro- i mali przedsiębiorcy zatrudniający łącznie do 49 osób (ponad połowa jest na zdecydowanie tak). W grupie przedsiębiorstw zatrudniających powyżej 50 osób najwięcej odpowiedzi przypadało na „raczej tak” - ponad 61\%, natomiast rozkład pozostałych ocen w tej grupie był stosunkowo proporcjonalny.

Kolejne pytanie (B), które zadano przedsiębiorcom, dotyczyło wejścia Polski do strefy euro. Połowa przedsiębiorców jest na „raczej tak”, ale tylko 3,1\% jest zdecydowanym zwolennikiem akcesji. Oznacza to, że ponad 53\% właścicieli MSP jest zwolennikami przyjęcia wspólnej waluty. Na uwagę zasługuje fakt, że tylko $15,6 \%$ badanych jest zdecydowanym przeciwnikiem tego procesu.

fy euro?, Projekt badawczy NPB, http://www.nbp.pl/badania/seminaria_bise/PuchalskaO.pdf (3.10.2013), s. 5 .

${ }^{22}$ R. Morawczyński, Bariery eksportu matych i średnich przedsiębiorstw w województwie matopolskim, http://www.statsoft.p1/ksiazki/book51.html (30.10.2013); W. Czemiel-Grzybowska, Rola pomocy publicznej w procesie konwergencji, Uniwersytet Ekonomiczny we Wrocławiu, „Zeszyty Naukowe", nr 280/2013, s. 95-102. 
Tabela 1. Odpowiedzi przedsiębiorców na pytania: A. Czy decyzja o przystąpieniu Polski do UE była słuszna - z perspektywy działalności Pańskiej firmy?; B. Czy jest Pan/Pani zwolennikiem wejścia Polski do strefy euro? (w \%)

\begin{tabular}{|c|c|c|c|c|c|c|c|}
\hline PYT. & $\begin{array}{c}\text { LICZBA } \\
\text { ZATRUDNIONYCH }\end{array}$ & ZDECYDOWANIE TAK & RACZEJ TAK & RACZEJ NIE & ZDECYDOWANIE NIE & NIE WIEM & $\begin{array}{c}\text { SUMA } \\
\text { KOŃCOWA }\end{array}$ \\
\hline \multirow{4}{*}{ A } & do 9 & 55,6 & 22,2 & 11,1 & 11,1 & 0,0 & 100,0 \\
\hline & $10-49$ & 53,3 & 46,7 & 0,0 & 0,0 & 0,0 & 100,0 \\
\hline & 50-249 & 13,5 & 61,5 & 12,5 & 12,5 & 0,0 & 100,0 \\
\hline & Suma końcowa & 51,0 & 37,9 & 5,6 & 5,6 & 0,0 & 100,0 \\
\hline \multirow{4}{*}{ B } & do 9 & 11,1 & 33,3 & 11,1 & 44,4 & 0,0 & 100,0 \\
\hline & $10-49$ & 0,0 & 53,3 & 40,0 & 0,0 & 6,7 & 100,0 \\
\hline & 50-249 & 0,0 & 62,5 & 25,0 & 12 & 0,0 & 100,0 \\
\hline & Suma końcowa & 3,1 & 50,0 & 28,1 & 15,6 & 3,1 & 100,0 \\
\hline
\end{tabular}

Źródło: badania własne.

Tabela 2. Opinie przedsiębiorców na temat potencjalnych konsekwencji, jakie niesie przystąpienie do strefy euro - z perspektywy ich firm (C) (w \%)

\begin{tabular}{|c|l|c|c|c|c|c|c|}
\hline \multirow{2}{*}{ PYt. } & \multicolumn{1}{|c|}{$\begin{array}{c}\text { LICZBA } \\
\text { ZATRUDNIONYCH }\end{array}$} & $\begin{array}{c}\text { ZDECYDOWANIE } \\
\text { POZYTYWNE }\end{array}$ & $\begin{array}{c}\text { RACZEJ } \\
\text { POZYTYWNE }\end{array}$ & $\begin{array}{c}\text { RACZEJ } \\
\text { NEGATYWNE }\end{array}$ & $\begin{array}{c}\text { ZDECYDOWANIE } \\
\text { NEGATYWNE }\end{array}$ & $\begin{array}{c}\text { NIE } \\
\text { WIEM }\end{array}$ & $\begin{array}{c}\text { SUMA } \\
\text { KOŃCOWA }\end{array}$ \\
\hline \multirow{4}{*}{ C } & do 9 & 11,1 & 33,3 & 33,3 & 11,1 & 11,1 & 100,0 \\
\cline { 2 - 8 } & $10-49$ & 6,7 & 33,3 & 46,7 & 0,0 & 13,3 & 100,0 \\
\cline { 2 - 8 } & $50-249$ & 6,0 & 62,5 & 12,5 & 25,0 & 0,0 & 100,0 \\
\cline { 2 - 8 } & 250 i więcej & 50,0 & 25,0 & 25,0 & 0,0 & 0,0 & 100,0 \\
\cline { 2 - 8 } & Suma końcowa & 11,1 & 38,9 & 33,3 & 8,3 & 8,3 & 100,0 \\
\hline
\end{tabular}

Źródło: badania własne.

Etap wstępny badania zakończono zadaniem pytania C: jakie będą konsekwencje wejścia do strefy euro dla firmy? (tabela 2.). Po analizie zebranych odpowiedzi należy stwierdzić, że przedsiębiorcy konsekwentnie utrzymują, że przystąpienie do strefy euro będzie miało pozytywny wpływ na ich biznes. Odpowiedzi „zdecydowanie pozytywnie” i „raczej pozytywnie” wskazało $50 \%$ badanych, natomiast $41,6 \%$ jest zdania, że proces ten będzie miał raczej lub zdecydowanie negatywny wpływ. Potwierdza to wyniki badań prezentowane w literaturze, dotyczących opinii przedsiębiorców na temat potencjalnego wpływu wejścia do strefy euro na ich przedsiębiorstwa ${ }^{23}$. W kolejnych

${ }^{23}$ A. Rogut, Koszty i zagrożenia zwiazane z wejściem Polski do strefy euro, [w:] P. Kowalewski, G. Tchorek (red.), Mechanizmy funkcjonowania strefy euro, NBP, 2010, s. 205; M. Rozkrut, Raport na temat korzyści i kosztów przystapienia Polski do strefy euro, NBP, 2010 www.nbportal. pl (30.10.2013); K. Puchalska, op. cit., s. 5. 
etapach badania postanowiono więc zweryfikować, jakie są obawy przedsiębiorców oraz jakie szanse dla swoich przedsiębiorstw upatrują oni w przyjęciu wspólnej waluty.

\section{KONSEKWENCJE WEJŚCIA DO STREFY EURO}

W kolejnym etapie badania przedsiębiorcom przedstawiono scenariusze potencjalnych konsekwencji i poproszono ich o wskazanie maksymalnie czterech, ich zdaniem najważniejszych (z katalogu 16 pozycji) w kontekście działalności ich firmy. Opierając się na uzyskanych odpowiedziach, opracowano ranking (tabela 3.).

Tabela 3. Oczekiwane przez przedsiębiorców konsekwencje po wejściu do strefy euro

\begin{tabular}{|c|l|c|}
\hline Poz. & \multicolumn{1}{|c|}{ KonsEKWENCJA } & RANKING [\%] \\
\hline 1. & Eliminacja ryzyka kursowego w stosunku do euro & 44,4 \\
\hline 2. & Eliminację kosztów transakcyjnych wynikających z wymiany PLN na Euro & 41,7 \\
\hline 3. & Zagrożenie utraty partnerów handlowych spoza strefy euro & 27,3 \\
\hline 4. & Wzrost przejrzystości rynków & 25,0 \\
\hline 5. & Zwiększenie konkurencji ze strony zagranicznych firm & 22,6 \\
\hline 6. & Zmiana popytu na produkty mojej firmy & 21,9 \\
\hline 7. & Spadek stóp procentowych & 9,4 \\
\hline 8. & Ożywienie wymiany handlowej z zagranicą & 8,8 \\
\hline 9. & Inne & 6,3 \\
\hline
\end{tabular}

Źródło: badania własne.

$\mathrm{Na}$ pierwszym miejscu, zdaniem badanych, jest eliminacja ryzyka kursowego, które utrudnia planowanie i prowadzenie działalności gospodarczej oraz generuje ryzyko. W efekcie niektórzy przedsiębiorcy mogą nawet rezygnować $\mathrm{z}$ wymiany handlowej z obawy przed poniesieniem strat. Przedsiębiorcy są świadomi, że eliminacja ryzyka kursowego jest szansą na poprawę warunków prowadzenia działalności gospodarczej poprzez redukcję niepewności co do przyszłych przychodów i kosztów oraz niwelację ryzyka inwestycyjnego Polski w oczach inwestora zagranicznego. $\mathrm{Na}$ drugim miejscu w rankingu znajduje się redukcja kosztów kursowych i transakcyjnych. Stanowi ona istotne ułatwienie ${ }^{24}$, przez chociażby likwidację uciążliwych marż oraz opłat za operację wymiany walut w kantorach i bankach. Korzyści z eliminacji kosz-

${ }^{24}$ J. Werwińska, € jak euro, ODDK, Gdańsk 2002, s. 21-22. 
tów transakcyjnych są tym większe, im więcej jest dokonywanych operacji wymiany. Przedsiębiorstwa pozbawione tego obciążenia finansowego są w stanie przeznaczać dodatkowe strumienie pieniężne na inwestycje oraz tworzyć nowe miejsca pracy. Po trzecie, przedsiębiorcy obawiają się, że wprowadzenie euro w Polsce spowoduje utratę ich dotychczasowych kontrahentów spoza tej strefy. Wynika to ze specyfiki miejsca funkcjonowania badanych przedsiębiorstw oraz faktu, że większa część transakcji eksport/import odbywa się z krajami znajdującymi się blisko wschodniej granicy: Litwą, Białorusią, Ukrainą. Badani przedsiębiorcy na czwartym miejscu wskazują wzrost przejrzystości rynku. Oferowane przez kontrahentów ceny, wyrażone w euro będą porównywalne do cen oferowanych przez firmy z Polski. a przedsiębiorcy uzyskają możliwość pozyskania lub poszerzenia współpracy z zagranicznymi dostawcami. Wyeliminuje to ponoszone przez nich koszty finansowe i ryzyko finansowe. Na piątym miejscu przedsiębiorcy spodziewają się zwiększenia konkurencji ze strony zagranicznych firm. Przyjęcie euro poprawi porównywalność cen pomiędzy krajami i w konsekwencji prowadzi do wzrostu konkurencji na rynku dóbr i usług ${ }^{25}$. Koszty transakcyjne i wahania kursowe umożliwiają funkcjonowanie mniej efektywnych podmiotów oferujących towary po wyższej cenie niż mogłyby to zrobić inne podmioty. Firmy MSP obawiają się, że walcząc o klienta będą wciąż musiały dążyć nie tylko do poprawy efektywności, jakości, ale też obniżenia kosztów i - w konsekwencji - do obniżenia cen. Pozytywnym aspektem jest to, że zwiększona konkurencja pobudzi ich innowacyjność i pozwoli na napływ najnowszych technologii i know-how, które są kluczowe dla wzrostu gospodarczego. Kolejne, szóste miejsce zajmuje niejako konsekwencja zwiększenia konkurencji oraz utraty partnerów spoza strefy euro, czyli zmiana popytu na produkty firmy, siódme zaś - spadek stóp procentowych. Po przystąpieniu do strefy euro istotnie wzrośnie wiarygodność Polski w oczach inwestorów. Znajdzie to także odzwierciedlenie w poprawie oceny wiarygodności kredytowej podmiotów gospodarczych, spowoduje obniżenie kosztu pozyskania kapitału przez podmioty gospodarcze. Przedsiębiorstwa będą mogły realizować przedsięwzięcia, które dotychczas podejmowały w ograniczonym stopniu albo w ogóle nie mogły być podejmowane, ze względu na ograniczenia finansowe. Dopiero ósmą pozycję w rankingu zajmuje ożywienie wymiany handlowej z zagranicą. Konsekwencją eliminacji ryzyka kursowego i niepewności dotyczącej kształtowania się przyszłych przychodów oraz kosztów eksporterów i importerów. Rozwój handlu sprzyja korzyściom wynikają-

${ }_{25}$ W. Czemiel-Grzybowska, Zarzadzanie przedsiębiorstwem spotecznym w procesie konwergencji, Wyd. SEDno, Warszawa 2012, s. 11-40. 
cym ze specjalizacji oraz skali produkcji i prowadzi do wzrostu inwestycji koniecznych dla zwiększenia możliwości produkcyjnych.

\section{ZAKOŃCZENIE}

Należy zauważyć, że wśród badanych przedsiębiorstw stwierdzono przewagę tych, popierających akcesję Polski do strefy euro. Sytuacja przedsiębiorców przez pryzmat powyższego badania wydaje się jednak złożona. $Z$ jednej strony są oni zwolennikami wprowadzenia wspólnej waluty, ale poparcie jest tu znacznie niższe niż $\mathrm{w}$ dużych przedsiębiorstwach ${ }^{26}$. Prawdopodobnie przyczyn takiego nastawienia należy upatrywać $\mathrm{w}$ tym, że nie wszystkie przedsiębiorstwa MSP mają kontakty handlowe lub finansowe w strefie euro, więc trudno jest im oszacować kierunek wpływu wprowadzenia wspólnej waluty na ich sytuację. Postawione na wstępie pytanie: czy przedsiębiorcy są zwolennikami przystąpienia do unii walutowej należy w perspektywie przeprowadzonego badania zweryfikować pozytywnie.

Badani przedsiębiorcy spodziewają się głównie korzyści z akcesji, o czym świadczą dwie najmocniejsze pozycje w rankingu: eliminacja ryzyka oraz redukcja kosztów transakcyjnych co świadczy o wysokiej świadomości, że akcesja uprości i przyspieszy ich rozliczenia obrocie gospodarczym. Jednocześnie tej aprobacie towarzyszy nieumiejętność przewidywania wpływu uczestnictwa w strefie euro na strategie konkurencji oraz niepewność udziału w obrocie międzynarodowym. Trudno więc o jednoznaczną odpowiedź na ostatnie pytanie postawione na wstępie. O ile na pierwszą część pytania: czy zredukuje koszty działania, należy odpowiedzieć, przez pryzmat oczekiwanych korzyści chociażby w postaci redukcji kosztów transakcyjnych, pozytywnie, to dalsza jego część wymaga pogłębionych badań. Przedsiębiorcy nie oczekują poprawy konkurencyjności ich przedsiębiorstw, a wręcz przeciwnie - obawiają się utraty kontrahentów spoza strefy euro i przegranej na rynku międzynarodowym. Nie doceniają oni też zalet ożywienia wymiany handlowej - plasując ją na przedostatnim miejscu.

Zaprezentowane wyniki badań mają charakter poglądowy i dotyczą analizowanej próby. Obawy badanych przedsiębiorców, co do konsekwencji akcesji Polski do strefy euro, stanowią naturalną konsekwencję wyzwania, jakie sprawia zarządzanie firmą w zmiennym otoczeniu, ale mogą także wynikać z ich niskiego poziomu wiedzy. Konieczne staje się podjęcie dodatkowych badań, na 
reprezentatywnej próbie przedsiębiorstw, a także zwiększenie działań podnoszących wiedzę o procesie konwergencji wśród właścicieli MSP.

\section{BIBLIOGRAFIA}

Baldwin R., Taglioni D., Trade Effects of the Euro: a Comparison of Estimators, ,Journal of Economic Integration", Vol. 22, No. 4/2007, http://dx.doi.org/10.11130/ jei.2007.22.4.780.

Bris A., Koskinen Y., Nilsson M., The real effects of the euro: evidence from corporate investments, CEPR, Discussion Paper, No. 4521, http://dx.doi.org/10.2139/ ssrn.559941.

Brouthers L.E., Nakos G. et al., Key Factors for Successful Export Performance for Small Firms, ,Journal of International Marketing", Vol. 17, No. 3/2009, http://dx.doi. org/10.1509/jimk.17.3.21.

Bun M.J.G., Klaassen F.J.G.M., The Euro Effect on Trade is not as Large as Commonly Thought, „Oxford Bulletin of Economics and Statistics”, No. 69/2007, http:// dx.doi.org/10.1111/j.1468-0084.2007.00448.x

Capstaff J., Marshall A., Hutton J., The Introduction of the .Euro and Derivative Use in French Firms, "Journal of International Financial Management \& Accounting", Vol. 18/2007, http://dx.doi.org/10.1111/j.1467-646x.2007.01005.x.

Cohen B.J., The future of the euro: Let's get real, „Review of International Political Econo$m y ”$, Vol. 19, No. 4/2012, „RIPE Focus on Governing Global Finance and Banking", http://dx.doi.org/10.1080/09692290.2012.715089.

Crespo N., Fontoura M.P., Intra-Industry Trade by Types: What Can We Learn from Portuguese Data?, „Review of World Economics”, Vol. 140, No. 1/2004, http:// dx.doi.org/10.1007/bf02659710.

Crozet M., Lalanne G., Poncet S., Wholesalers in international trade, „European Economic Review", Vol. 58/2013, http://dx.doi.org/10.1016/j.euroecorev.2012.10.005.

Czemiel-Grzybowska W., Rola pomocy publicznej w procesie konwergencji, Zeszyty Naukowe 280/2013, Uniwersytet Ekonomiczny we Wrocławiu.

Czemiel-Grzybowska W., Zarządzanie przedsiębiorstwem spotecznym w procesie konwergencji, Wyd. SEDNO, Warszawa 2012.

Frieden J., The Euro: Who Wins? Who Loses?, „Foreign Policy”, No. 112/1998, http:// dx.doi.org/10.2307/1149033.

Gorynia M., Dzikowska M., Jankowska B., Pietrzykowski M., Tarka P., Wptyw przyjęcia euro na międzynarodowa konkurencyjnośc przedsiębiorstw, „Gospodarka Narodowa", nr 4/ 2009, s. 1-23.

Gorynia M., Dzikowska M., Jankowska B., Pietrzykowski M., Tarka P., Przystapienie Polski do strefy euro a międzynarodowa konkurencyjnośc i internacjonalizacja polskich przedsiębiorstw, „Ekonomista”, nr 4/2011.

Gorynia M., Dzikowska M., Jankowska B., Pietrzykowski M., Tarka P., Opportunities and Threats Related to Accession of Poland to the Euro Zone - Perspective of Po- 
lish Enterprises, The Mechanism of Functioning of EMU Euro Zone Enlargement The New Members Perspective, Wydawnictwo Uniwersytetu Łódzkiego, Łódź 2010. Gorynia M., Luka konkurencyjna na poziomie przedsiębiorstwa a przystapienie Polski do Unii Europejskiej. Implikacje dla strategii firm i polityki gospodarczej, Wydawnictwo AE w Poznaniu, Poznań 2002.

Henning C.R., Europe's Expanding Currency: Fiscal Stability and Democratic Legitimacy, „Review of International Political Economy”, Vol. 14, No. 5/2007.

Hung Y. W., Nguyen H., Exchange rate exposure and the use of foreign currency derivatives in the Australian resources sector, "Journal of Multinational Financial Management", Vol. 22, No. 4/2012, http://dx.doi.org/10.1016/j.mulfin.2012.06.003.

Kilon J., Handel zagraniczny w procesie konwergencji - metodyka badań przedsiębiorstw handlowych województwa podlaskiego, „Ekonomia i Prawo”, B. Polszakiewicz, J. Boehlke (red.), t. 12, nr 4/2013.

Lane P. R., The Real Effects of European Monetary Union, „The Journal of Economic Perspectives", Vol. 20, No. 4/2006, http://dx.doi.org/10.1257/jep.20.4.47.

Micco A., Stein E., Ordoñez G., The Currency Union Effect on Trade: Early Evidence from EMU, „Economic Policy”, Vol. 18, No. 37/2003, http://dx.doi. org/10.1111/1468-0327.00109 1.

Morawczyński R., Bariery eksportu matych i srednich przedsiębiorstw w województwie matopolskim, http://www.statsoft.pl/ksiazki/book51.html (30.10.2013).

Nguyen H., Faff R., Marshall A., Exchange rate exposure, foreign currency derivatives, and the introduction of euro: French evidence, "International Review of Economics and finance", Vol. 16, No. 4/2007, http://dx.doi.org/10.1016/j.iref.2006.01.002.

Portes R., Rey H. et al., The Emergence of the Euro as an International Currency, „Economic Policy", Vol. 13, No. 26/1998, http://dx.doi.org/10.1111/1468-0327.00034.

Puchalska K., Koszty dostosowawcze oraz korzyści z wprowadzenia euro dla sektora polskich przedsiębiorstw niefinansowych. Czego oczekuja polskie przedsiębiorstwa po przystapieniu do strefy euro?, Projekt badawczy NPB, http://www.nbp.pl/badania/ seminaria_bise/PuchalskaO.pdf (3.10.2013).

Rogut A., Koszty i zagrożenia związane z wejsciem Polski do strefy euro, [w:] P. Kowalewski, G. Tchorek (red.), Mechanizmy funkcjonowania strefy euro, NBP, 2010.

Rose A.K., One Money, One Market: Estimating the Effect of Common Currencies on Trade, „Economic Policy”, No. 15/2000, http://dx.doi.org/10.1111/1468-0327.00056.

Rozkrut M., Raport na temat korzyści i kosztów przystapienia Polski do strefy euro, http://www.nbportal.pl/r/euro/materialy_papierowe_pdf/raport_euro/re19.pdf (30.10.2013).

Shambaugh J.C., Reis R., Rey H., The Euro's Three Crises, „Brookings Papers on Economic Activity", Spring 2012, http://dx.doi.org/10.1353/eca.2012.0006.

Werwińska J., € jak euro, ODDK, Gdańsk 2002. 